Asian-Australasian Journal of

Food Safety and Security

ISSN 2523-1073 (Print) 2523-2983 (Online)

www.ebupress.com/journal/aajfss

\title{
Article \\ Effect of dietary probiotics on the growth performance, meat quality improvement of broiler chicken for safe meat production
}

\author{
Md. Sazedul Karim Sarker ${ }^{1 *}$, Md. Masud Rana ${ }^{2}$, Shabiha Sultana ${ }^{1}$, Nathu Ram Sarker ${ }^{1}$ and Talukder Nurun \\ $\mathrm{Nahar}^{3}$ \\ ${ }^{1}$ Poultry Production Research Division, Bangladesh Livestock Research Institute, Savar, Dhaka 1341, \\ Bangladesh \\ ${ }^{2}$ Department of Animal Science, Chonbuk National University, Deokjin-gu, Jeonju, Jeollabuk-do, South Korea \\ ${ }^{3}$ Director General, Bangladesh Livestock Research Institute, Savar, Dhaka 1341, Bangladesh
}

*Corresponding author: Dr. Md. Sazedul Karim Sarker, Senior Scientific Officer, Poultry Production Research Division, Bangladesh Livestock Research Institute, Savar, Dhaka 1341, Bangladesh. Phone: +8801712223635 ; E-mail: sazdulkarim@yahoo.com

Received: 07 November 2017/Accepted: 21 November 2017/ Published: 21 November 2017

\begin{abstract}
A feeding trial was conducted to investigate the effect of Probiotic (Biofast) on the growth performance and meat quality of broiler chicken. Ninety six 1-d-old mix sexed Cobb 500 broiler chicks were obtained from a local commercial hatchery. Chicks were randomly allocated in 2 experimental treatments for 5 wk. The experimental treatments received a 1) control, 2) control with probiotic Biofast $0.055 \%$ (bacillus subtilis-100\%) in the diet. Both treatments had 48 broilers arranged in 4 replicates of 12 broilers each. Eight birds from 2 different groups (one/replication) were sacrificed on termination of the feeding trial of breast, thigh to investigate the meat quality. Feed intake in treatment $T_{1}$ was significantly $(P>0.05)$ greater than control in 0 to 3 weeks of age. Though in starter phase treatments failed to induce any marked effects on body weight, weight gain and FCR but numerically increased in $\mathrm{T}_{1}$ than control. In finisher period (4-5 wks), there were no significant differences on body weight, weight gain, feed intake and FCR between the treatments. The organ weight like liver, heart, kidney, spleen, gizzard, abdominal fat and intestine weight also did not show any significant differences between the dietary treatments of control and Biofast. In addition, though the dressing $\%$ was not significantly different but numerically higher percentage was found by using Biofast. Similarly, no significant differences $(\mathrm{p}>0.05)$ were found in $\mathrm{pH}$, cooking loss, meat color and TBA values between the treatments. In conclusion, supplementation of Biofast in diet has no significant effect on the growth performance of broiler chicks though it has got some positive effects on other parameters that indirectly revealed to enhance meat quality of broiler chicken as well as food safety issues.
\end{abstract}

Keywords: broiler chicken; probiotics; growth performance; meat quality; safe meat

\section{Introduction}

There is an increasing demand for quality in animal products, as well as concern about the effect of these products on human health. For this reason, animal production systems will have to focus not only on obtaining high production, but also on their impact on the environment as well as on human and animal health (Ferket, 2003). Consumer has also been increasingly accepting alternative therapies which include probiotics, in replacing synthetic drugs. Moreover, their use in the poultry industry has increased as potential alternatives to antibiotics use as growth promoter, and in select cases, for controlling specific enteric pathogens (Ezema, 2013). Probiotics are feed additives that contain live microorganisms and promote beneficial effects on the host of favoring the balance of the intestinal microbes (Fuller, 1989). In many countries of the world, including Bangladesh the use of most antibiotics growth promoter (AGP) has been banned to preserve the effectiveness of 
important human drugs (Casewell, 2003). Recently, alternatives for substituting these traditional growth promoters have been evaluated and probiotics feeding have been the area of interest. The probiotics include live bacteria, yeast, their metabolites and $\mathrm{pH}$ adjusters, which contribute to maintain balance in intestinal microflora (Islam et al., 2004). Therefore, probiotics has been used as natural biological non-feed additives which have beneficial effects to poultry by improving its intestinal microbial balance to stimulate the processes of digestion and absorption of nutrients (Pelicano et al., 2002). Probiotic microorganisms are responsible for the production of vitamin B complex and digestive enzymes for stimulation of intestinal immunity, increasing protection against toxins produced by pathogenic organisms. In broiler nutrition, probiotic species such as Lactobacillus, Streptococcus, Bacillus, Bifidobacterium, Enterococcus, Aspergillus, Candida, and Saccharomyces are widely used to prevent poultry pathogens and diseases and improve broiler's growth performance (Zulkifli et al., 2000; Kabir et al., 2004). Probiotic act as a mono or mixed culture of living microorganisms which beneficially affect the host by improving the properties of the indigenous microflora. The use of Bacillus subtilis spores as a probiotic or a direct-fed microorganism could be an alternative to adding to feed for better growth performances and immunity of broiler. In Bangladesh, most of the feed company export probiotic from foreign countries. Since there have been a few investigations on the effects of Bacillus subtilis in broiler feed. Recently, Biofast which is $100 \%$ Bacillus subtilis could be used to supplement with feed for better growth performances and immunity of broiler. Meanwhile, the challenge for nutritionists will be to obtain well-balanced cost effective feed which will be free from antibiotics and ensure the safety of poultry products for consumers. These factors may be critical in the Bangladesh, where most of the farmers have been used antibiotics into their poultry feed to enhance birds performance and disease resistant capacity. The poultry feed industry needs adequate information on this aspect to augment commercial broiler production in Bangladesh. Furthermore, there is a way to increase the use of probiotics in diets for animals, which is a more reasonable option, since they do not leave residues in the environment, in the animal body and do not cause cross-resistance in men compared with antibiotics (Nepomuceno and Andreatti, 2000). In this context, this study was undertaken to evaluate the effect of probiotic (Biofast powder) which is supplemented in diets on performance and carcass characteristics of broilers from 1 to 35 days.

\section{Materials and Methods}

\subsection{Birds and housing}

Ninety six 1-d-old mix sexed Cobb broilers were obtained from a local commercial hatchery. Broilers were randomly allocated in 2 experimental treatments for $5 \mathrm{wk}$. Each treatment had 48 broilers arranged in 4 replicates of 12 broilers each. Each replicate was assigned to a clean floor pen $\left(2 \mathrm{~m}^{2}\right)$ and birds were raised on a rice straw based litter. Heat was provided with a heating lamp per pen. The ambient temperature in experimental house was maintained at $32^{\circ} \mathrm{C}$ during the first week and thereafter decreased by $3^{\circ} \mathrm{C}$ in the third week, and finally fixed at $22^{\circ} \mathrm{C}$ up to end of the experiment. The experiment lasted for 35 day.

\subsection{Dietary treatments}

To meet the nutrient requirements of the broiler chicken over this period, a complete basal diet was formulated for each of the 2 stages of growth; starter and finisher. The diets were formulated to meet the nutrients requirements of broilers as recommended by the National Research Council (NRC, 1994). The experimental treatments received a 1) control, 2) control with probiotic Biofast $0.055 \%$ (Bacillus subtilis-100\%). Biofast was prepared according to manufacturer instructions $(4500 \mathrm{~g}$ rice polish should be mixed with $250 \mathrm{~g}$ Biofast powder. $1 \mathrm{~kg}$ from that mixture needed for the preparation of $100 \mathrm{~kg}$ poultry feed). The basal diet was formulated for starter ( 1 to $21 \mathrm{~d}$ ) and finisher ( 22 to $35 \mathrm{~d}$ ) of broiler growth periods and its composition is shown in Table 1. The basal diet was prepared in each week and stored in sacks and was kept in a cool place. Experimental diets and water were provided ad libitum.

\subsection{Growth performance traits}

Growth performance parameters such as body weight (BW), weight gain (WG), feed intake (FI), and feed conversion ratio (FCR), were determined every week. Starter (0-3 wks) and finisher (4-5wks) BW gain, FI, and FCR were calculated for the whole duration of the experiment.

\subsection{Organ weights and carcass yield percentages}

At the end of experiment, after weighing, 4 birds per treatment were randomly selected and killed by cervical dislocation. The liver, heart, kidney, spleen gizzard, abdominal fat and intestine were excised and weighed. Afterward, the birds were scalded, defeathered, and carcasses were eviscerated. The head and feet were 
removed, and calculated as a percentage of live body weight and also carefully examined to detect any pathological lesion or damages. The weight of intestine was also measured and recorded.

\subsection{Meat characteristics}

Muscular $\mathrm{pH}$ values were determined on Pectorals major muscle with a needle probe $24 \mathrm{~h}$ post mortem with Mettler MP 120-B digital pH-meter. All pH measurements were conducted on the anterior end of the right breast. The $\mathrm{pH}$ meter was standardized by a two-point method against standard buffers of $\mathrm{pH} 4.0$ and $\mathrm{pH}$ 7.0. Cooking loss was analyzed as [sample weight before cooking minus sample weight after cooking] $\times 100 /$ sample weight before cooking. The colour of breast meat was determined after $24 \mathrm{~h}$ of cooling the carcass with Minolta CR-400 colorimeter (MINOLTA CAMERA Co. Ltd., Osaka, Japan) calibrated against white plate (CIE $\mathrm{L}^{*}$ - lightness, $\mathrm{a}^{*}$ - redness, $\mathrm{b}^{*}-$ yellowness) with $8 \mathrm{~mm}$ optical probe diameter, D65 illuminant and $2^{\circ}$ observer. The meat colour is presented as CIE-L*a*b* (Commission Internationale de l'Eclairage, 1976). Depending on the colour breast meat samples were classified into following groups: DFD $\left(\mathrm{L}^{*}<\mathrm{L}^{*} 44\right)$ - Soares et al. $(2002,2009)$.

Meat samples (5 g) from each breast cut were used for the analysis of the thiobarbituric acid reactive substances (TBARS) by using the aqueous acid extraction method of Pikul et al. (1989) to determine lipid oxidation. The reaction produces a red color which can be measured using a spectrophotometer.

\subsection{Statistical analysis}

All data were subjected to analysis of variance procedures appropriate for a completely randomized design using the general linear model procedures of SAS (SAS Inst. Inc., Cary, NC 2005). The mean differences among different treatments were separated by Duncan's multiple range tests. A level of $(\mathrm{P}<0.05)$ was used as the criterion for statistical significance.

\section{Results and Discussion}

This study indicated that feed intake in treatment $\mathrm{T}_{1}$ was significantly $(\mathrm{P}>0.05)$ greater than control in 0 to 3 weeks of age (Table 2). Though in starter phase treatments failed to induce any marked effects on body weight, weight gain and FCR but numerically increased in $T_{1}$ than control. In Table 3 , there were no significant differences on body weight, weight gain, feed intake and FCR between the treatments $\left(T_{0}, T_{1}\right)$ during the finisher phase in this trial. A significant difference in feed intake between the treatments was observed in the period of 0-21 days of age. In agreement with the present results, Boratto et al. (2004) reported that there were no significant differences in weight gain of chicken given diets with or without Bacillus subtilis in the diet. Another group of researcher reported that the inoculation of probiotics has no effect on weight gains (Rocha et al., 2010; Takahashi et al. 2005) and feed consumption (Cavit, 2004; Yalcinkayal et al., 2008) but reduce feed intake which was verified by Zulkifli et al. (2000).

The obtained data showed that there no significant different in body weight with control groups during study. But Probiotic showed numerically the higher body weight than that of control. These results suggested that probiotics used as a feed supplement in diet of poultry to enhance productive performance and immune responses (Higgins et al., 2008). In this regard the dietary supplementation of probiotic have beneficial effect on the host animal by stimulating appetite (Nahashon et al., 1992), stimulate the immune system (Koenen et al., 2004), produce the endogenous digestive enzymes (Saarela et al., 2000), decrease $\mathrm{pH}$ and release bacteriocins (Rolfe, 2000). According to Ramarao et al. (2004) it was also not possible to observe any influence of probiotics on broiler weight gain, as opposed to Kabir et al. (2004), who obtained higher weight gain in broilers fed a probiotic product. Our results also did not find any differences between two groups due to the variation of microbial culture used in the probiotics, application level, feed composition, age and strain of the bird. The parameter feed conversion ratio was not statistically different between treatments in none of the studied intervals, but in starter phase numerically lower in probiotic than control, as also observed in the experiment of Loddi et al. (2000), who worked with a probiotic product containing Enterococcus faecium $(1 \times 1010 \mathrm{CFU} / \mathrm{g}$ product), other authors, however, obtained better feed conversion ratio in broilers fed probiotics in the periods of 0-21 days (Zulkifli et al., 2000; Maiorka et al., 2001; Corrêa et al, 2003; Pelicano et al., 2004a) and 0-40 days (Maiorka et al., 2001; Boratto et al., 2004). But in finisher phase we found no difference with control group.

The organ weight like liver, heart, kidney, spleen, gizzard, abdominal fat and intestine weight did not show any significant differences between the dietary treatments of Biofast and control. But, abdominal fat was numerically lower than control. Boratto et al. (2004) found increased liver size of poultry reared in environment inoculated with bacteria, which may be related to the neutralization of toxic substances produced from the 
metabolic activity of intestinal bacteria, which requires a constant energy expenditure made by the liver for detoxification inducing the hypertrophy of hepatocytes. He found the total amount of edible offal and gizzard was higher for poultry fed diets supplemented with probiotics. But our results were opposed to his findings. In addition, though the dressing $\%$ was not significantly different but numerically higher number found on $\mathrm{T}_{1}$ (Biofast) treatment though Boratto et al. (2004) found carcass yield percentages were higher for the nonprobiotic-fed femalebroilers than for the control. This points to the fact that probiotic causes suppression in production and processing performance traits.

Table 1-1. Composition of basal diet for the broiler starter and finisher diet.

\begin{tabular}{lll}
\hline Item & Starter (1-21d) & Finisher (22-35 d) \\
\hline Ingredient (\%) & 52 & \\
Maize & 6 & 60 \\
Protein concentrate & 4.6 & 7.4 \\
Rice polish & 33.3 & 3 \\
Soybean & 1 & 25.6 \\
Di calcium phosphate & 0.25 & 1 \\
Vitamin-mineral premix & 0.5 & 0.25 \\
Salt & 1.9 & 0.5 \\
Oil & 0.1 & 2 \\
Lysine & 0.1 & 0.1 \\
Methionine & 0.5 & 0.1 \\
Limestone & & 0.3 \\
\hline Calculated analysis (per kg of diet) & 10.64 & \\
\hline Moisture (\%) & 7.16 & 13.47 \\
Ash & 22.69 & 6.06 \\
CP(g) & 3.44 & 16.49 \\
Fat & 4.31 & 7.22 \\
Fiber & & 4.62 \\
\hline
\end{tabular}

Table 1-2. Proximate analysis of broiler breast and thigh meat.

\begin{tabular}{lllllll}
\hline Treatment & \multirow{2}{*}{ Meat } & \multicolumn{5}{c}{ Proximate analysis (\% on fresh basis) } \\
\cline { 3 - 7 } & & Moisture & CP & EE & CF & Ash \\
\hline Control & Breast & 68.29 & 23.06 & 4.87 & 0.60 & 1.86 \\
Biofast & & 65.79 & 23.04 & 3.46 & 0.50 & 1.98 \\
Control & \multirow{2}{*}{ Thigh } & 73.69 & 20.22 & 3.24 & 0.70 & 1.72 \\
Biofast & & 69.70 & 19.30 & 2.41 & 0.75 & 1.64 \\
\hline
\end{tabular}

Table 2. Broiler growth performance on starter phase (0-3 weeks).

\begin{tabular}{lllll}
\hline Treatment & Body weight $(\mathbf{g})$ & Weight gain $(\mathbf{g})$ & Feed intake $(\mathbf{g})$ & FCR \\
\hline $\mathrm{T}_{0}$ & 761.54 & 716.54 & $849.40^{\mathrm{b}}$ & 1.185 \\
$\mathrm{~T}_{1}$ & 766.32 & 721.32 & $857.18^{\mathrm{a}}$ & 1.187 \\
$\mathrm{SEM}$ & 3.705 & 3.812 & 1.793 & 0.007 \\
$\mathrm{P}-$ Value & 0.56 & 0.57 & 0.012 & 0.87 \\
\hline
\end{tabular}

* $\mathrm{T}_{0}=$ control, $\mathrm{T}_{1=}$ Biofast

Table 3. Broiler growth performance on finisher phase (4-5 weeks).

\begin{tabular}{lllll}
\hline Treatment & Body weight $(\mathbf{g})$ & Weight gain $(\mathbf{g})$ & Feed intake $(\mathbf{g})$ & FCR \\
\hline $\mathrm{T}_{0}$ & 1818.54 & 1102.21 & 2100.15 & 1.9 \\
$\mathrm{~T}_{1}$ & 1836.08 & 1101.72 & 2099.72 & 1.9 \\
$\mathrm{SEM}$ & 11.167 & 2.254 & 15.296 & 0.014 \\
P-Value & 0.47 & 0.92 & 0.99 & 0.93 \\
\hline
\end{tabular}

$* \mathrm{~T}_{0=}$ control, $\mathrm{T}_{1=}$ Biofast 
Table 4. Effects of dietary treatments on absolute organ weights (g) of broiler chickens.

\begin{tabular}{lllllllll}
\hline Treatment & Liver & Heart & Kidney & Spleen & Gizzard & Abdominal fat & Intestine & Dressing \% \\
\hline $\mathrm{T}_{0}$ & 42.00 & 11.75 & 4.75 & 2.75 & 56.25 & 19.50 & 144.75 & 71.58 \\
$\mathrm{~T}_{1}$ & 40.50 & 11.75 & 4.75 & 2.75 & 52.50 & 17.25 & 140.00 & 72.40 \\
$\mathrm{SEM}$ & 0.548 & 0.411 & 0.453 & 0.25 & 1.266 & 1.164 & 1.889 & 0.264 \\
$\mathrm{P}-$ Value & 0.11 & 1.00 & 1.00 & 1.00 & 0.14 & 0.37 & 0.23 & 0.12 \\
\hline
\end{tabular}

Table 5. Different meat quality characteristics of broiler feeding with dietary Probiotic (Biofast).

\begin{tabular}{llllll}
\hline \multirow{2}{*}{ Treatment } & \multirow{2}{*}{$\mathbf{p}^{\mathbf{H}}$} & \multirow{2}{*}{ Cooking loss } & \multicolumn{3}{c}{ Color values } \\
\cline { 4 - 6 } & & 18.36 & $\mathbf{L}$ & $\mathbf{a}^{*}$ & $\mathbf{b}^{*}$ \\
$\mathrm{~T}_{0}$ & 6.30 & 18.25 & 51.23 & 3.48 & 9.01 \\
$\mathrm{~T}_{1}$ & 6.23 & 0.814 & 53.33 & 4.44 & 8.21 \\
$\mathrm{SEM}$ & 0.054 & 0.95 & 0.724 & 0.406 & 0.232 \\
$\mathrm{P}-$ Value & 0.56 & 0.16 & 0.26 & 0.07 \\
\hline
\end{tabular}

* Meat color values of lightness $\left(\mathrm{L}^{*}\right)$, redness $\left(\mathrm{a}^{*}\right)$, and yellowness $\left(\mathrm{b}^{*}\right)$

Table 6. Thiobarbituric acid (TBA) value of broiler feeding with Biofast.

\begin{tabular}{ll}
\hline Treatment & TBA Value \\
\hline $\mathrm{T}_{0}$ & 8.81 \\
$\mathrm{~T}_{1}$ & 8.63 \\
$\mathrm{SEM}$ & 0.566 \\
$\mathrm{P}-$ Value & 0.344 \\
\hline
\end{tabular}

Table 7. European Production Efficiency Factor (European Broiler Index).

\begin{tabular}{llc}
\hline Item & $\begin{array}{l}\text { Control } \\
(\mathbf{n = 4 8})\end{array}$ & $\begin{array}{c}\text { Dietary treatment } \\
\text { Probiotic (Biofast) } \\
(\mathbf{n = 4 8})\end{array}$ \\
\hline FCR $(0-5 w k s)$ & 1.84 & 1.83 \\
Mortality $(0-5 w k s)$ & 2.08 & 2.08 \\
Percentage & 276.42 & 280.68 \\
*EPEF & & \\
\hline
\end{tabular}

$* \mathrm{EPEF}=$ European Poultry Efficiency Factor (Average gram gained/day $\times \%$ Survival rate $/ \mathrm{FCR} \times 10$ ).

No significant differences $(\mathrm{p}>0.05)$ were found in $\mathrm{pH}$, cooking loss and meat color between the treatments as shown in Table 5. According to Ludtke (2009), due to the rapid metabolic transformation of glycogen into lactic acid, which results in achieving ultimate $\mathrm{pH}$ before carcass cools, causing protein denaturation, and consequently, meat becomes pale, soft, and exudative. In probiotic, pH value was slightly lower than control. In control, lightness of meat was numerically higher than probiotic. $L^{*}$ value is the main parameter that determines poultry meat color. Color is one of the main indicators of the quality of most foods. This sensorial quality has a high influence of the meat purchase decision and its acceptance by consumers. It is an important functional quality and it is closely related to other qualities, such as $\mathrm{pH}$, water holding capacity, emulsifying capacity, and texture. Whereas tenderness is one of the main sensorial attributes that determine global acceptability, meat color is associated to acceptability at purchase (Bressan and Beraquet, 2002; Sanders et al., 1997). In Table 6 represented that thiobarbituric acid (TBA) values were not significantly different between the treatments. According to Gheisari (2011), the extent of oxidative rancidity in a fat may also be determined by its TBA number. The 2- thiobarbituric acid (TBA) test is believed to measure the breakdown products of unsaturated fatty acid oxidation. Typically, the TBA number of a sample shows a steady increase as it becomes more rancid, but a certain amount of variation is found between the TBA numbers obtained for similar fresh samples. In this study the Biofast showed numerically decreased number than the control. The mortality percentage and the European production efficiency factor are presented in Table 7 . The mortality rate was same $(2.08 \%)$ for both the group $(2.08 \%)$. The European production efficiency factor was greater for the Biofastsupplemented group (280.68) than control group (276.42). 


\section{Conclusions}

The addition of the probiotic product, Biofast to broiler diets didn't show significant influence on the performance compared to those of control but showed numerically higher body weight, dressing percentage and higher European Broiler Index and at the same time lowered abdominal fat and cooking losses. It can be concluded that probiotic has some positive effects on the parameters that indirectly revealed to enhance meat quality of broiler chicken as well as food safety issues. Further follow-up study is necessary to determine Biofast inoculation levels in the broiler diet.

\section{Conflict of interest}

None to declare.

\section{References}

Boratto AJ, 2004. Uso de antibiótico, de probiótico e de homeopatia, inoculadosounão com Escherichia coli, parafrangos de cortecriadosemconforto. Revista Brasileira de Zootecnia, 36: 1477-1485.

Bressan MC and NJ Beraquet, 2002. Efeito de fatorespré-abate sobre a qualidade da carne de peito de frango. Ciên.Agrotec., 26:1049-1059.

Casewell M, C Friis, E. Marco, P McMullin and I Phillips, 2003. The European ban on growth-promoting antibiotics and emerging consequences for human and animal health. J. Antimicrob. Chemother., 52: 159161.

CIE, 1978. International Commission on Illumination, Recommendations on Uniform Color Spaces, Color Difference Equations, Psychometric Color Terms. Supplement No. 2to CIE publication No. 15 (E-1.3.1) 1971/(TC-1.3) 1978. Bureau Central de la CIE, Paris, France.

Corrêa GSS, 2003. Efeitos de antibiótico e probióticossobredesempenho e rendimento de carcaçadefrangos de corte, 2003. Ar. Brasil. Med. Vet.Zootec., 55.

Ezema C, 2013. Probiotics in animal production: a review. J. Vet. Med. Anim. Health., 5: 308-316.

Ferket PR, 2003. Manutenção da saúde intestinal em um mundosemantibióticos. Arq. Brasil. de Med. Vet. Zootec., 55(4).

Fuller R, 1989. A review: probiotics in man and animals. J. Appl. Microbiol., 66: 365-378.

Gheisari HR, 2011. Correlation between acid, TBA, peroxide and iodine values, catalase and glutathione peroxidase activities of chicken, cattle and camel meat during refrigerated storage. Vet. World., 4: 153-157.

Higgins SE, JP Higgins, AD Wolfenden, SN Henderson, A Torres-Rodriguez, G Tellez and B Hargis, 2008. Evaluation of a lactobacillus-based probiotic culture for the reduction of Salmonella enteritidis in neonatal broiler chicks. Poult. Sci., 87:27-31.

Islam MW, MM Rahman, SML Kabir, SM Kamruzzaman and MN Islam, 2004. Effects of probiotics supplementation on growth performance and certain haemato-biochemical parametersin broiler chickens. Bangladesh J. Vet. Med., 2: 39-43.

Kabir, SML, MM Rahman and MB Rahman, 2004. The dynamics of probiotics on growth performance and immune response in broilers. Int. J. Poult. Sci., 3:361-364.

Koenen ME, J Karmer, R VanDerHulst, L Heres, SH Jeurissen and WJ Boersma, 2004. Immuno-modulation by probiotic lactobacilli in layer and meat-type chickens. Br. Poult. Sci., 45: 355-366.

Loddi MM, 2000. Uso de probiótico e antibióticosobre o desempenho, o rendimento e a qualidade de carcaça de frangos de corte. Revista Brasileira de Zootecnia, 2: 1124-1131.

Ludtke CH, CEW Nogueira, W Bertoloni, OA Dalla Costa and GJD Soares, 2009. Bem-estar animal no transporte de suínos e suainfluêncianaqualidade da carne e nosparâmetrosfisiológicos do estresse [comunicadoTécnico 475]. Concórdia: EMBRAPA Suínos e Aves.

Maiorka A, E Santin and SM Sugeta, 2001. Utilização de prébióticos, probióticos e simbióticosemdietasparafrangos. Revista Brasileira de Ciência Avicola, 3: 75-82.

Nahashon SN, HS Nakaue and LW Mirosh, 1992. Effect of direct fed microbials on nutrient retention and production parameters of laying pullets. Poult. Sci., 71 (suppl. 1): 111 (Abstr).

Nepomuceno ES and RLF Andreatti, 2000. Probióticos e prebióticos na avicultura. In: Simpósio de Sanidade Avícola, Santa Maria. Anais. Concórdia: Embrapa Suínos e Aves, 1: 45-55.

Pelicano ERL, RA Souza and HBA Souza, 2004a. Productive traits of broiler chickens fed diets containing differents growth promoters. Brazilian Journal of Poultry Science, 6: 177-182.

Pikul $\mathbf{J}$ and FA Kummerow, 1991. Thiobarbituric acid reactive substance formation as affected by distribution of polyenoic fatty acids in individual phospholipids. J. Agri. Food. Chem., 39: 451-457. 
Ramarao SV, MR Reddy and MVLN Raju, 2004. Growth, nutrient utilization competence in broiler chicken fed probiotic, gut acidifier and antibacterial compounds. Indian J. Poult. Sci., 39:125-130.

Rocha AP, RD Abreu and MCMM Costa, 2010. Prebióticos, ácidos orgânicos e probióticos em rações para frangos de corte. Revista Brasileira de Saúde e Produção Animal, v: 793-801.

Rolfe RD, 2000. The role of probiotic cultures in the control of gastrointestinal health. J. Nutr., 130: 396S-402S.

Saarela M, G Mogensen, R Fondén, J Mättö and T Mattila-Sandholm., 2000. Probiotic bacteria: safety, functional and technological properties. Journal Biotech., 84: 197-215.

SAS, 2005. SAS/STAT User's Guide, Version 6.12. SAS.Inst. Inc., Cary, NC. Simon O. Mico-Organisms Fed Additive -Probiotic. Advances in Pork Production. 16: 161-167.

Takahashi SE, AA Mendes and ESPB Saldanha, 2005. Efficiency of prebiotics and probiotics on the performance, yield, meat quality and presence of Salmonella spp. in carcasses of free-range broiler chickens. Revis. Brasil. Ciên. Avíc., 7: 151-157.

Yalcinkaya L, T Gungor, M Basalan and E Erdem, 2008. Mannan Oligosaccharides MOS from Saccharomyces cerevisiae in boilers: effects on performance and blood biochemistry. Turkey J. Vet. Anim. Sci., 32: 43-48.

Zhao TP and MP Doyle, 2009. Inactivation of Salmonella and Escherichia coli O157:H7 on lettuce and poultry skin by contamination of levulinic acid and sodium dodecyl sulfate. J. Food Prot., 72: 928-936.

Zulkifli I, 2000. Growth performance and immune response of two commercial broiler strains fed diets containing Lactobacillus cultures and oxytetracycline under heat stress conditions. Br. Poult. Sci., 41: 593597. 